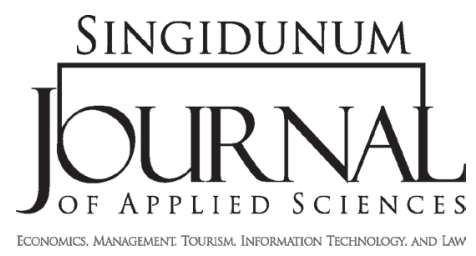

SINGIDUNUM JOURNAL 2012, 9 (2): 74-79.

ISSN 2217-8090

UDK $342.731(497.7)$

Review paper/Pregledni naučni rad

\title{
LEGAL FRAMEWORK OF FREEDOM OF RELIGION IN THE REPUBLIC OF MACEDONIA
}

\author{
Saša Dukoski ${ }^{1}$, Svetlana Veljanovska ${ }^{*}, 1$ \\ ${ }^{1}$ University St. Kliment Ohridski, Faculty of Law - Kičevo, \\ Rudnička Street, Kičevo, Republic of Macedonia
}

\begin{abstract}
:
Guarantee of freedom of religion and its regulation with international and regional legal instruments is undoubtedly the foundation of every modern democracy.

However, elaborating freedom of conscience and religion has to be done within the framework of a positive legal system, i.e. Laws and the Constitution, which underlie the concept of organizing the state itself.

Religious beliefs have been present for millenniums and their beginnings are in the very essence of both humans and communities, and even countries. The Republic of Macedonia along with all other states which were once part of the common Yugoslav federation has two periods of treatment of the issue of religious freedom, i.e. the freedom of conscience and religion. The well-known concept of separation of religious feelings from the statelegal system was practiced in the former common federation. Relying on that concept and upon gaining independence, the Republic of Macedonia has developed a different, primarily symbiotic blend of the state with its two biggest religious communities, thus attempting to deal with this extremely sensitive issue, more or less successfully, which is actually the basic principle of human freedoms.
\end{abstract}

\section{Key words:}

religion,

Freedom of conscience,

Constitution,

Law,

church,

religious community.

\section{INTERNATIONAL}

\section{LAWS AND REGULATIONS}

Various international documents regulate human rights. According to numerous legal theoreticians, the right to freedom of religion or belief is perhaps the most essential one, underpinning individual as well as collective philosophy of life.

The contents of the Right to freedom of religion or religious belief are regulated with a large number of covenants, resolutions, protocols, and agreements. The most important of all is the United Nations Universal Declaration of Human Rights, which was adopted in 1948 . The International Covenant on Civil and Political Rights, adopted in 1966 and the European Convention for the Protection of Human Rights and Fundamental Freedoms are also extremely relevant for this issue.
However, the initial defining of the framework parameters of national jurisdiction elaborates on freedom of religion or belief in the following most important international instruments for regulating human rights, in particular:

- Articles 18 and 29 of the Universal Declaration of Human Rights;

- Articles 4, 18 and 27 of the International Covenant on Civil and Political Rights;

- Article 1 of the Declaration on the Elimination of All Forms of Intolerance and of Discrimination Based on Religion or Belief;

- Article 9 of the European Convention for Protection of Human Rights and Basic Liberties (European Convention for the Protection of Human Rights and Fundamental Freedoms); 
All these covenants and declarations as well a great number of other similar documents have been ratified by the Parliament of the Republic Macedonia, thus forming an integral part of the national legislation.

The overview of the domestic legal framework on freedom of religion or belief and religious demography in the former Yugoslav Republic of Macedonia is best given in the Report of the Special Rapporteur on freedom of religion or belief, Asma Jahangir, at the 13th meeting of the Human Rights Council, Agenda item 3. Promotion and protection of all human rights, civil, political, economic, social and cultural rights, including the right to development.

In the present report, the Special Rapporteur on freedom of religion or belief gives an overview of her mandate activities with regard to communications sent to States concerning individual cases, her participation in recent conferences and meetings, country visits undertaken by the Special Rapporteur and further follow-up activities of the mandate.

In addition, the Special Rapporteur discusses early warning signs of discrimination and violence on the grounds or in the name of religion or belief. These early warning signs relate to action, or inaction, by State actors, non-State actors and international or external factors.

There are 31 missions mentioned in the report and they took place from October 1987 to November 2009. Among them was the monitoring mission to the Former Yugoslav Republic of Macedonia, which was conducted in April 2009, Report No: A/ HRC/13/40/Add.2 (Jahangir, 2009).

The Points 52 and 53 of the same report state the following regarding the role of the State:

States have the main responsibility for implementing international human rights standards, including the promotion and protection of freedom of religion or belief. On the one hand, States must refrain from violating freedom of religion or belief and, on the other hand, they also have the obligation to protect persons under their jurisdiction from violation of their rights, including abuses committed by non-State actors. Measures should not only consist in prosecuting the perpetrators of such acts and providing compensation to the victims, but also in devising specific preventive action in order to prevent the recurrence of such acts in future.

The legislative and executive branches should adopt non-discriminatory laws and policies which aim at achieving equality. Domestic legislation must also be in conformity with article 20, paragraph 2, of the International Covenant on Civil and Political Rights. Indeed, incitement to religious hatred can be an indicator of emerging tensions, and the relevant authorities should find the most effective ways to protect individuals against others' advocacy of hatred and violence. Reagarding that, an independent and impartial judiciary, which examines each case on its own merits, is vital to ensuring that neither religious freedom nor freedom of expression is unduly restricted. Part of the international documents related to legal regulation of freedom of religion is certainly the Report of the Special Rapporteur on freedom of religion or belief, Asma Jahangir, presented at the $13^{\text {th }}$ meeting of the UN's Human Rights Council on December 28, 2009, submitted to the General Assembly.

Although freedom of religion was generally positively assessed, in the part of the Report on Conclusions and Recommendations, particularly in point 58 , it is precisely put: "In terms of inter-religious tensions, both within the Orthodox Church and within the Islamic Community, the Special Repporteur would like to remind the Government of its obligations to remain neutral and non-discriminatory, especially regarding registration procedure" (Jahangir, 2009).

\section{NATIONAL REGULATIVE}

The relations between the state and its religious communities and the work of religious communities, i.e. freedom and rights of religion in the Republic of Macedonia, have always been an issue of versatile perception, both during the period of the common Yugoslav state and in the period after gaining its independence.

Immediately after the end of World War II, i.e. in 1946, a Law on prohibition of incitement to and spreading national, racial and religious hatred and contention was adopted. Apart from the national, this law provides religious equality as well, which includes equality of religious communities.

This was followed by the Law on the Legal Position of Religious Communities adopted in 1953, the Act from 1961 for establishing certain regulations from the Law on the Legal Position of Religious Communities, which were in a way the basis for further legal regulation or more precisely, additional clarification of certain states through law decisions in 1977, 1997 and 2007. 
All these laws consider the freedom of conscience and religion as a private human matter, putting an emphasis on the concept of separation of religious communities from the state and providing freedom of performing religious rituals and religious rites. Law norms have introduced prohibition of misuse of religion for political reasons, but they have also been quite liberal in providing the possibility for religious communities to be able to acquire and own property as well as to set up religious schools for educating priests.

However, from a normative perspective, the relations between religious communities and religious groups and the state are regulated by the Constitution of the Republic of Macedonia, the Law on state authorities and Law on churches, religious communities and religious groups.

Generally, the freedom of religion in the Republic of Macedonia after it became legally independent from the former Yugoslav federation with the Constitution of the Republic of Macedonia, is guaranteed, in particular in Article 19, which has been supplemented with Amendment 7 from the Constitution of the Republic of Macedonia, where it is precisely stated that:

Freedom of religion is guaranteed.

Free and public, individually or in a community with others, expression of religion is guaranteed.

Macedonian Orthodox Church, other religious communities and religious groups are separated from the state and stand equal before the law.

Macedonian Orthodox Church, other religious communities and religious groups are free to establish religious schools and social institutions and charities in accordance with the procedure foreseen by the law (Ustav na Republika Makedonija, 1991).

However, this article has undergone certain redefining with the Constitution Amendment VII, which was adopted after the events in 2001. It stipulates the following:

1. Macedonian Orthodox Church as well as the Islamic Religious Community in the Republic of Macedonia, the Catholic Church, the Evangelist-Methodist Church, the Jewish Community and other religious communities and religious groups are separated from the state and stand equal before the law.

2. Macedonian Orthodox Church as well as the Islamic Religious Community in the Republic of Macedonia, the Catholic Church, the Evangelist-Methodist Church, the Jewish Community and other religious communities and religious groups are free to establish religious schools and social institutions and charities in accordance with a procedure foreseen by the law.

3. Point 1 from this amendment replaces paragraph 3 from Article 19, whereas point 2 replaces paragraph 4 from Article 19 of the Constitution of the Republic of Macedonia (Amandmani na Ustavot na Republika Makedonija, 2001).

Due to such changes in the Constitution, the law that was in force at the time had to be changed, and that was the Law on regulating the right of religious communities in the Republic of Macedonia. Therefore, the Law on legal position of church, religious communities and religious groups was adopted in 2007 (Zakon za pravnata položba na crkva, verska zaednica i religiozna grupa, 2007).

This law, or more precisely, the Article 2, states the following: "A church, a religious community and a religious group, according to this law, is a voluntary community of physical entities who with their religious belief and sources of their doctrine practice the freedom of religion united by faith and identity expressed through equal performance of religious service, prayers, rites and other religious expressions".

Article 4 in the existing law stipulates that: "Religious discrimination is not allowed".

Religious belief does not exemplary the citizen from the obligations he has as a citizen according to the Constitution, the laws and other regulations, unless otherwise specified by the law or some other regulation.

In a procedure following the submitted initiative, the Constitutional court of the Republic of Macedonia abolished Articles 27, 28 and 29 from the existing Law with a Decision, which contained an elaborated section on religious education i.e. the opportunity to organize religious education within educational institutions as an optional subject in accordance with the law (Odluka na Ustavniot sud na Republika Makedonija, 2010).

What is extremely important for the defining of legal regulation on a norm about the right to freedom of religion is the Law on organization and work of government authorities which was used for the establishment of a Commission for Relations with Religious Communities and Religious Groups as a separate organ of the government authorities, with the status of a legal entity. 
Article 29 from the Law on organization and work of government authorities stipulates the following:

1. The Commission for Relations with Religious Communities and Religious Groups performs all activities related to legal position of religious communities and religious groups, as well as matters related to relations between the state, religious communities and religious groups.

2. The Commission for Relations with Religious Communities and Religious Groups has the status of a legal entity (Zakon za organizacija na rabota na organite na državnata uprava, 2000).

Accordingly, this Commission ensures the legal position of religious communities and religious groups and relations between the state, religious communities and religious groups.

What is interesting is that this kind of work has been practiced throughout the whole period of the existence of the Republic of Macedonia, i.e. both when it was in the common Yugoslav state and after gaining its independence.

As an institution established for religious affairs, the Commission appeared for the first time in the period from 1944 to 1945 as a Religious Council. Later on, from 1945 until 1951, this organ was part of the Secretariat for Internal Affairs. The Commission was later transformed into an independent organ, which changed in a different way in different periods, although it has retained the same role. Thus, from 1951 to 1962, it existed as a Commission for Religious Matters, from 1963 to 1976 as a Republic Commission for Religious Matters, from 1977 to 2000 as a Republic Commission for Relations with Religious Communities, and from 2000 onwards as a Commission for Relations with Religious Communities and Religious Groups.

The Commission has a Sector for affairs concerning relations with religious communities and religious groups with two departments:

Department for determining legal position of religious communities and religious groups;

Department for determining relations between the state, religious communities and religious groups;

As a sort of proclaimed principle of religious freedom, another matter to be elaborated on is observing religious holidays, part of which are public holidays, and the rest are holidays of the Republic
Dukoski S., Veljanovska S. $\diamond$ Legal framework of freedom of religion

of Macedonia. Another category that should also be mentioned here are the so called "Non-working days for believers".

Public holidays in the Republic of Macedonia, which have explicit national as well as religious nature include: May 24, "Ss. Cyril and Methodius" -Slavic Educators Day; December 8 - "St. Kliment Ohridski Day".

The group of holidays of the Republic of Macedonia include: Christmas, First day of Christmas, January 7 according to the Orthodox calendar; Easter, the second day of Easter according to the Orthodox calendar; Ramazan Bayrami, the first day of Ramazan Bayrami."

There is another, much larger group of so called: Non-working days for believers, and they include: the non-working days for Orthodox Christians: Christmas Eve, a day before Christmas; January 19, Theophany (Twelfth night); Good Friday, Friday before Easter, August 28, The Assumption of the Blessed Virgin Mary (Great Virgin Mary) and Pentecost, the Friday before Pentecost.

For Muslims, a non-working day is: Kurban Bayram, the first day of Kurban Bayram; Yom Kippur, the first day of Yom Kippur is a non-working day for members of the Jewish community;

Christmas Day, the second day of Easter and All Saints' day according to the Gregorian calendar are non-working days for the Catholics; January 27, St. Sava is a non- working day for members of the Serbian community (Zakon za praznicite na Republika Makedonija, 1998; Zakon za izmenuvanje na Zakonot za praznicite na Republika Makedonija, 2007).

\section{RELIGIOUS COMMUNITIES AND GROUPS REGISTERED IN THE REPUBLIC OF MACEDONIA}

According to the register, 15 churches, 7 religious communities and 7 religious groups have been registered in the Republic of Macedonia.

In terms of religious demography, the official census from 2002 shows that the Macedonian Orthodox Church has approximately 1,300,000 believers, which amounts to $65 \%$ of the country's population. Less than $2 \%$ of the total population is from other Christian communities, including the Catholic Church (about 7,000 believers), United Methodist Church (about 1,300 believers) and the Seventh - day Adventist Church (about 500 believers). 
The second biggest community is the Islamic Religious Community of the Republic of Macedonia with about 674,000 believers, which means that Muslims amount to approximately one third of the entire population (Jahangir, 2009).

In the register run by the Commission for Relations with Religious Communities and Religious Groups such as churches in the Republic of Macedonia, the following churches have been registered: Macedonian Orthodox Church - Ohrid Archbishopric; Catholic Church in the Republic of Macedonia; Evangelist-Methodist Church in the Republic of Macedonia; Christian Adventist Church (SeventhDay Church of Adventists) in the Republic of Macedonia; Christian Adventists Church in the Republic of Macedonia; Christian Baptist Church „Joyful News"; Evangelist-Congressional Church; New Apostolic Church of Macedonia; Evangelical Church in the Republic of Macedonia; Christian Center in the Republic of Macedonia; the Church of God in the Republic of Macedonia; God's voice Christian Church; Christian Church of Good Tidings in the Republic of Macedonia; Apostolic Reformed Church in the Republic of Macedonia; Church of Jesus Christ of Latter-Day Saints in Macedonia;

Religious communities that have been entered into the public register include the following: Islamic Religious Community of the Republic of Macedonia; Jewish Community of the Republic of Macedonia; Jehovah's Witnesses - Christian Religious Community; Holy Seat and Crown of the Islamic Erenleric Tarikat Religious Community in Macedonia; Sathya Sai Center - Skopje; Vaishna Religious Community 'Iskon' -Macedonia; Great Ancient Christian Community- Universal life.

There are seven religious groups registered in the Republic of Macedonia: Christian Church Word of Hope; Seventh-Day Adventist Reform Movement; Christian movement New Hope; Kaderic religious group- Jennet; Free Evangelical Church - Good tidings; Ehlibejt Bektashi Religious group in Macedonia; Christian Church - Oasis in RM; Ehli Sunnet Vel Dzemat.

There is an assumed connection between nationality and religion in the Republic of Macedonia. Namely, the majority of Orthodox believers are ethnic Macedonians, whereas the majority of the Muslims are ethnic Albanians. If you consider this from a constitutional perspective, the majority of Orthodox believers are ethnic Macedonians and most Serbs and Vlachs who live in the Republic of
Macedonia. On the other hand, Muslims are usually Albanians who live in the Republic of Macedonia, as well as the Turkish, Roma and Bosnian people. According to certain census statistics, atheists make up less than $1 \%$ of the population.

\section{CONCLUSION}

The Republic of Macedonia is a multi - ethnic, multicultural and multi-religious country which, from a normative-legal aspect, respects religious differences and freedom of religion i.e. belief.

Although nationality and religion are basically two different identities, they often overlap here, thus members of one church or religious community are considered to be members of a certain community i.e. nationality.

According to their capacity and influence, the members of the Orthodox religion, personified through the Macedonian Orthodox church - Ohrid Archbishopric and the Islamic Religious Community are dominant both in the field of religious doctrines and the social life in general. However, there are additional 14 churches, 6 religious communities and 7 religious groups in the country, which function more or less successfully and without any obstacles.

Nevertheless, if the general assessment of freedom of religion is positive, the legal system provides framework for freedom of religion and belief. The Republic of Macedonia was monitored during 2009 by the UN Human Rights Council, and an official report was submitted to the General Assembly.

Freedom of religion is currently and is likely to be in the future basically in correlation with the entire relation of the community, in particular the interaction of the relation people-people, Christianity-Islam.

\section{REFERENCES}

Amandmani na Ustavot na Republika Makedonija (2001) Služben vesnik na RM. br. 91/01 [online]. Available from: http://www.slvesnik.com.mk/Issues/4565B8A8 CCA245AC99E52A0EE60B3FCD.pdf [accessed 1 September 2012]. (in Macedonian)

European Convention for the Protection of Human Rights and Fundamental Freedoms. Council of Europe [online]. Available from: http://conventions.coe.int/Treaty/Commun/QueVoulezVous.asp?NT=005\&CL=ENG [accessed 21 June 2012 ]. 
Frčkoski-Danilov, Lj. (2005) Megunarodno pravo za pravata na čovekot. 2. izd. Skopje: Magor. (in Macedonian)

Frčkoski Danilov, Lj. (2007) Pregovaranje vo konflikti na identiteti. Skopje: Templum. (in Macedonian)

International Covenant on Civil and Political Rights. OHCHR [online]. Available from: http://www2. ohchr.org/english/law/ccpr.htm [accessed 25 August 2012].

Jahangir, A. (2009) Report of the Special Rapporteur on freedom of religion or belief. United Nations. $\mathrm{Hu}-$ man Rights Council [online]. Available from: http:// www.sacw.net/IMG/pdf/G0910462.pdf [accessed 9 June 2012].

Murdok, Dž. (2008) Sloboda misli, savesti i veroispovesti: vodič za primenu člana 9 Evropske konvencije o ljudskim pravima : priručnik o ljudskim pravima. Beograd: Savet Evrope, Kancelarija u Beogradu. (in Serbian)

Odluka na Ustavniot sud na Republika Makedonija, U br. 104/2009 od 22 septemvri 2010 godina (2010) Služben vesnik na RM. br. 132/10 [online]. Available from: http://www.slvesnik.com.mk/Issues/ FC3140F7E810C747B3A8230E9D8E21C9.pdf [accessed 2 September 2012]. (in Macedonian)

Parekh, B. (2000) Rethinking Multiculturalism: cultural diversity and political theory. Cambridge, MA: Harvard University Press.

UN Declaration on the Elimination of All Forms of Intolerance and of Discrimination Based on Religion or Belief 1981. United Nations [online]. Available from: http://www.un.org/documents/ga/res/36/a36r055. htm [accessed 6 September 2012].

UN Universal Declaration of Human Rights. United Nations [online]. Available from: http://www.un.org/ en/documents/udhr/index.shtml [accessed 3 September 2012].

Ustav na Republika Makedonija (1991)Služben vesnik na RM. br. 52/91 [online]. Available from: http://www. slvesnik.com.mk/Issues/2D608B9363555A42AA3D7 A97CD4811DE.pdf [accessed 1 September 2012]. (in Macedonian)

Zakon za izmenuvanje na Zakonot za praznicite na Republika Makedonija (2007) Služben vesnik na RM. br. 18/07 [online]. Available from: http://www.slvesnik.com.mk/Issues/0708C07F60F4964493F94F D68E286F61.pdf [accessed 6 September 2012]. (in Macedonian)

Zakon za organizacija na rabota na organite na državnata uprava (2000) Služben vesnik na RM. br. 58/00 [online]. Available from: http://www.slvesnik.com. mk/Issues/C0C662559E3B4D6481A15690025F729E. pdf [accessed 15 June 2012]. (in Macedonian)

Zakon za pravnata položba na crkva, verska zaednica i religiozna grupa (2007) Služben vesnik na RM. br. 113/07 [online]. Available form: http://www.slvesnik.com.mk/Issues/B73B1AE48C6A854D9F63ECE819984E43.pdf [accessed 9 June 2012]. (in Macedonian)

Zakon za praznicite na Republika Makedonija (1998) Služben vesnik na RM. br. 21/98 [online]. Available from: http://www.slvesnik.com.mk/Issues/5574FD F10D4E4775ADA85C15530AB507.pdf [accessed 1 September 2012]. (in Macedonian)

\section{PRAVNI OKVIR SLOBODE VEROISPOVESTI U REPUBLICI MAKEDONIJI}

\section{Rezime:}

Garancija verskih sloboda i njena regulacija u okvirima međunarodnih i regionalnih pravnih instrumenata, bez sumnje je jedan od temelja svake savremene demokratije. Ipak eleboracija slobode savesti i veroispovesti od nesumnjive je važnosti u okvirima njenog tretmana od strane pozitivnog pravnog sistema, odnosno Zakona i Ustava koji su glavni opredeljivači koncepta uređivanja svake države.

Verska ubeđenja imaju mileniumski karakter i njihovi počeci utemeljeni su ne samo u ljudska bića,već i i same zajednice pa i u državama. Republika Makedonija kao i ostale države koje proizlaze iz zajedničke Jugoslovenske federacije imaju dva perioda uređenja po pitanjima verskih sloboda, odnosno slobode savesti i veroispovesti. Na bazi opštopoznatog koncepta odvojenosti religioznih osjećaja od državno-pravnog sistema, koji je bio praktikovan u bivšoj zajedničkoj federaciji,po osamostaljenjem u Republiku Makedoniju razvija se jedan drukčiji, pre svega simbiotski spoj države sa dvije najveće verske zajednice. Država pokušava,manje ili više uspešno da menagira sa ovim veoma osetljivim pitanjima koje su temeljni princip ljudskih prava i sloboda.

\section{Ključne reči:}

veroispovest, sloboda savesti, Ustav,

Zakon, crkva, verska zajednica.

Received: 07.09.2012. Correction: 25.09.2012.

Accepted: 05.10.2012. 